Binghamton University

The Open Repository @ Binghamton (The ORB)

$6-25-2019$

\title{
The Ethnohistory of Freshwater Use on Rapa Nui (Easter Island, Chile)
}

Sean W. Hixon

Penn State University

Robert J. Dinapoli

University of Oregon, rdinapol@uoregon.edu

Carl P. Lipo

Binghamton University--SUNY, clipo@binghamton.edu

Terry L. Hunt

University of Arizona, tlhunt@email.arizona.edu

Follow this and additional works at: https://orb.binghamton.edu/anthropology_fac

Part of the Archaeological Anthropology Commons

\section{Recommended Citation}

Hixon, Sean W.; Dinapoli, Robert J.; Lipo, Carl P.; and Hunt, Terry L., "The Ethnohistory of Freshwater Use on Rapa Nui (Easter Island, Chile)" (2019). Anthropology Faculty Scholarship. 42.

https://orb.binghamton.edu/anthropology_fac/42

This Article is brought to you for free and open access by the Anthropology at The Open Repository @ Binghamton (The ORB). It has been accepted for inclusion in Anthropology Faculty Scholarship by an authorized administrator of The Open Repository @ Binghamton (The ORB). For more information, please contact ORB@binghamton.edu. 


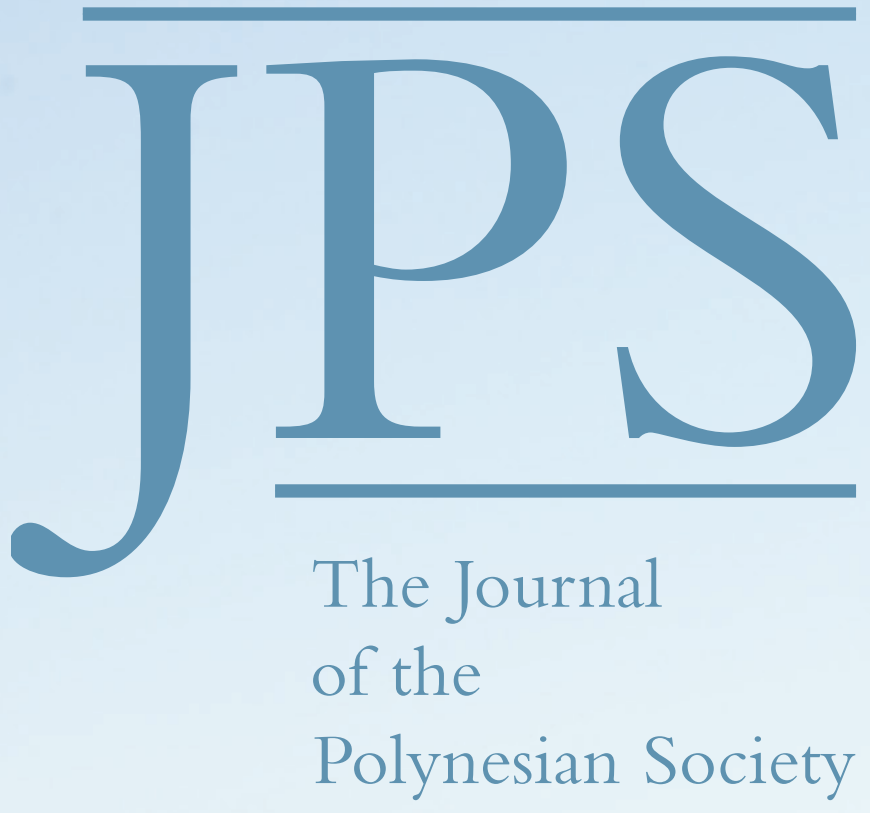

VOLUME 128 No.2 JUNE 2019

THE POLYNESIAN SOCIETY THE UNIVERSITY OF AUCKLAND

NEW ZEALAND

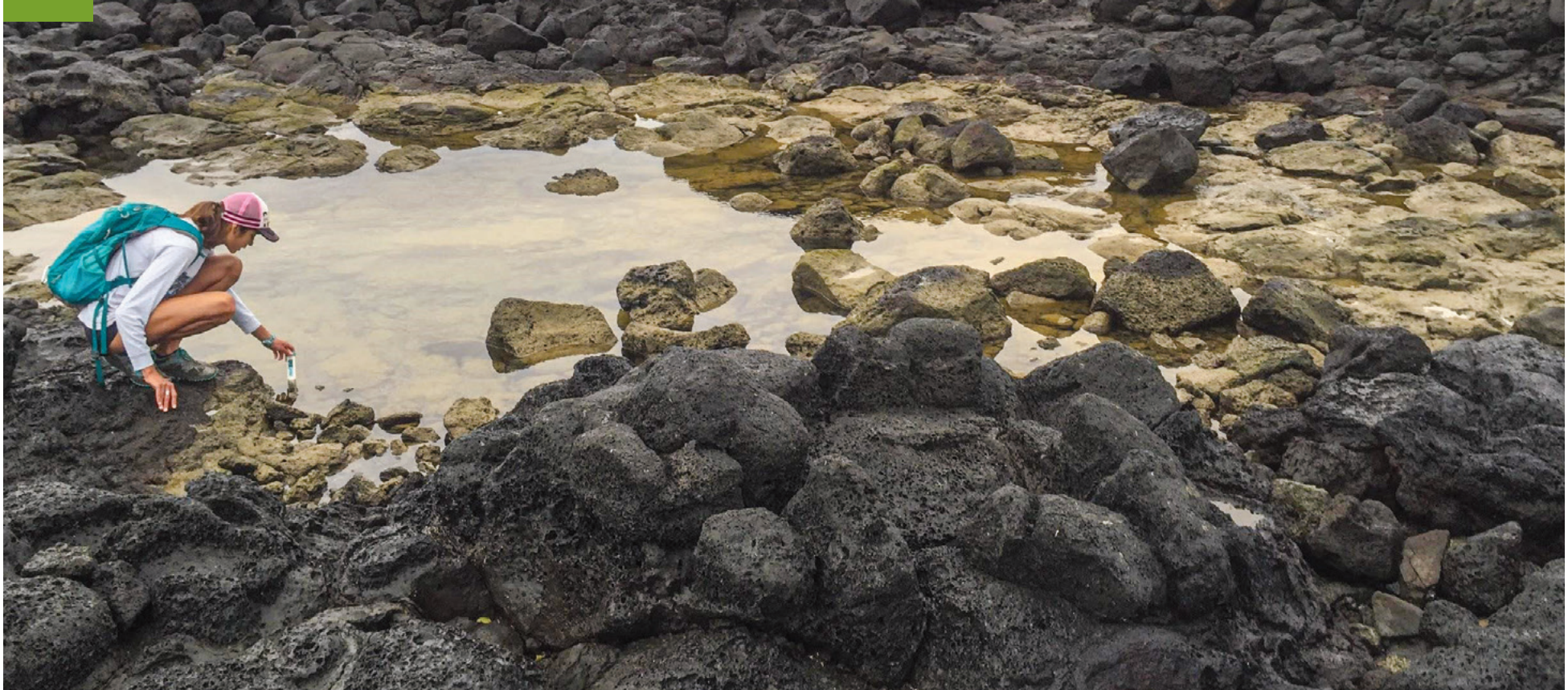




\title{
THE ETHNOHISTORY OF FRESHWATER USE ON RAPA NUI (EASTER ISLAND, CHILE)
}

\author{
SEAN W. HIXON \\ University of California at Santa Barbara \\ ROBERT J. DiNAPOLI \\ University of Oregon \\ CARL P. LIPO \\ Binghamton University \\ TERRY L. HUNT \\ University of Arizona
}

\begin{abstract}
Sources of drinking water on islands often present critical constraints to human habitation. On Rapa Nui (Easter Island, Chile), there is remarkably little surface fresh water due to the nature of the island's volcanic geology. While several lakes exist in volcanic craters, most rainwater quickly passes into the subsurface and emerges at coastal springs. Nevertheless, the island sustained a relatively large human population for hundreds of years, one that built an impressive array of monumental platforms (ahu) and statues (moai). To understand how Rapanui acquired their scarce fresh water, we review ethnohistoric data from first European arrival (1722) through the mid-twentieth century. Ethnohistoric accounts identify a diversity of freshwater sources and describe various Rapanui freshwater management strategies. Our findings highlight the importance of coastal freshwater seeps and provide much-needed insight into how Rapanui procured this vital and necessary resource.
\end{abstract}

Keywords: Rapa Nui (Easter Island), coastal springs, freshwater management, puna (wells), ethnohistory, Polynesia

Here is no safe anchorage; no wood for fuel; nor any fresh water worth taking on board.

_Captain James Cook, March 1774

Rapa Nui (Easter Island, Chile) evokes a rich array of superlatives, both positive and negative. On the one hand, the island boasts almost 1,000 multi-ton statues (moai), several hundred of which were transported across the volcanic landscape and placed on top of massive stone platforms (ahu) (Hochstetter et al. 2011). For these accomplishments, Rapa Nui is known as one of the world's greatest examples of prehistoric megalithic monument construction. On the other hand, the island is small $\left(164 \mathrm{~km}^{2}\right)$, remote (nearly 
2,000 km from Pitcairn Island and 3,500 km from the coast of Chile) and poorly endowed with natural resources (Fig. 1). The subtropical climate, variable rainfall, unproductive soils and lack of large coral reefs, lagoon or timber offered significant challenges to Rapanui. Among these challenges, the scarcity of drinking water may have been the greatest. Despite these limitations, Rapanui flourished and left a spectacular legacy.

Reliably sufficient fresh water is a biophysical constraint that determines whether habitats can support human communities. As Rapa Nui has unpredictable rainfall and lacks permanent streams, fresh water has always been a limited resource on the island. As Thomson (1891: 489) commented during his 1886 visit, "[T]he greatest mystery is how such a number of people obtained a sufficient supply of fresh water." While Rapa Nui does have a few crater lakes and numerous coastal freshwater seeps (Brosnan et al. 2018; Herrera and Custodio 2008), places to access freshwater resources are relatively scarce, patchy and likely predictable, which makes them good candidates for highly contested and "economically defendable" resources (Dyson-Hudson and Smith 1978; DiNapoli and Morrison 2017). Indeed, many argue that the distribution of this scarce yet vital resource had a major influence on the structure of Rapanui settlement locations and patterns of competitive interaction (e.g., DiNapoli et al. 2019; McCoy 1976; Rull 2016, 2018, 2019; Vogt and Kühlem 2018; Vogt and Moser 2010). Uncertainties and debates persist, however, about the range of freshwater sources used and which sources were likely the most important in the past. While ethnohistoric evidence can better resolve the locations and strategies of traditional freshwater procurement, as well the potential archaeological signatures of these strategies, the ethnohistoric record has been largely overlooked on this topic.

Here, we offer a systematic review of the Rapa Nui ethnohistoric accounts to better resolve patterns of traditional freshwater use and management. Using written accounts from European visitors to Rapa Nui between 1722 (Jacob Roggeveen) and 1955 (Thor Heyerdahl), we review known sources of fresh water and document strategies used by Rapanui for freshwater procurement and storage. We document the use of fresh water from both natural and constructed contexts including crater lakes, inland springs, coastal seeps, lava tubes/caves and constructed "wells" (puna), rainwater catchment basins (taheta) and reservoirs. We also briefly discuss historic accounts that describe the use of plants that may have had key roles in traditional Rapanui waterresource management. These historic accounts provide significant insight into the relative importance of different water procurement strategies and help provide the basis for generating hypotheses about Polynesian adaptations to freshwater scarcity and the influence of freshwater scarcity on Rapanui community patterning. While Rapanui used a range of freshwater sources, our review of the historical and archaeological evidence suggests that natural coastal seeps and constructed puna were likely of critical importance. 


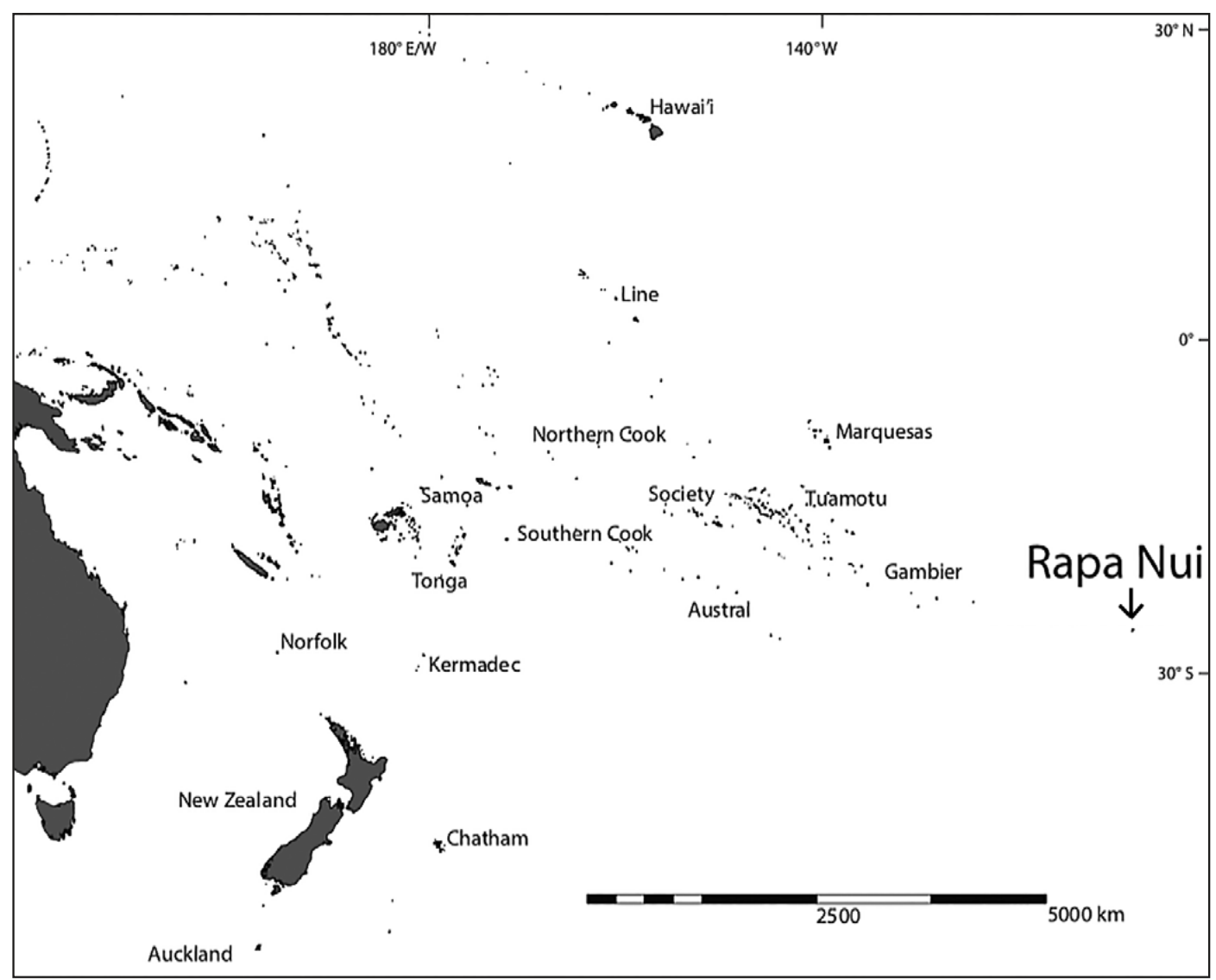

Figure 1. Location of Rapa Nui (Easter Island, Chile) in the southeastern Pacific.

\section{RAPA NUI HYDROGEOLOGY}

Rapa Nui is a volcanic island formed through hot-spot volcanism starting around 2.5 Myr (million years) ago (Bonatti et al. 1977; Vezzoli and Acocella 2009). Between 2.5 and 0.18 Myr ago, a series of eruptions created Poike and Rano Kau on the northeastern and southwestern corners of the island, respectively (Fig. 2). Starting approximately 360,000 kyr (thousand years) ago, numerous lava flows from two main fracture systems created Terevaka, which currently dominates the geology of the island. Lava flows that created Terevaka are quite young, and some date to as recently as $10 \mathrm{kyr}$ ago (Vezzoli and Acocella 2009).

These largely jointed basalt lava flows that characterise the island constitute what Herrera and Custodio (2008: 1333) term a large-scale "high permeability apron" and hold dramatic consequences for the hydrology of the island. Although the island enjoys abundant rainfall (a maximum of approximately $2,100 \mathrm{~mm} / \mathrm{yr}$ on the summit of Terevaka [Stevenson et al. 2015]), its porous substrate largely prevents the pooling of surface water and limits easy access 
for terrestrial flora and fauna (Herrera and Custodio 2008: 1331). Instead, the highly permeable volcanic apron rapidly transmits much of the water to the island's subterranean aquifer, which has elevations that average only a few metres above sea level (masl) (Brosnan et al. 2018; Zeferjahn 2016). Consequently, rain falling onto the surface of the island quickly vanishes and rarely (only intermittently after torrential downpours) forms streams or surface ponds. This phenomenon is often reflected in comments by visitors. For example, Brown ([1924] 1979: 25) noted that "a half an hour after a downpour the ground is as dry as before it" and that "the greatest defect of the island is its porous character".

Given Rapa Nui's porous substrate, water entering the ground flows through cracks and fractures in the bedrock. Where the land intersects the ocean, fresh groundwater seeps out into the sea (Fig. 3). This flow can occur at the surface as coastal springs or seeps, or underwater as submarine groundwater discharge (Kim et al. 2003; Montgomery \& Associates 2011), which is an overlooked water resource in many parts of the world (Moosdorf and Oehler 2017). The coastal fringe of the island, therefore, can offer locations for people to access groundwater relatively easily. On Rapa Nui, coastal springs exist in many areas along the coast and are easily accessible during low tide (Brosnan et al. 2018; Zeferjahn 2016).

The height of the water table on Rapa Nui is fairly low and typically between 1 and 3 masl (Álamos y Peralta 1992; Herrera and Custodio 2008; Montgomery \& Associates 2011). The amount of fresh water contained within the island is substantial, and significant flows emerge along the coast. Although there exist uncertainties in the values of coastal substrate transmissivity and hydraulic gradient, Montgomery \& Associates (2011) estimate a recharge rate of between 3,200 and 4,700 L/s. This rate is impressive when one considers that even a fraction of a percent of this discharge could supply a population of over 5,000 (Herrera and Custodio 2008: 1346).

Though accessible at the points where it emerges at the coast, these sources of water tend to be brackish due to the mixing of seawater with fresh groundwater in both surface and subsurface mixing zones. On Rapa Nui, this mixing zone is evidently thick, for salt water intrudes into near-coastal springs to create salinity levels of greater than $1,000 \mathrm{mg} / \mathrm{L} \mathrm{Cl}^{-}$(Herrera and Custodio 2008: 1329). While humans can survive with brackish water, there are limits to the salinity that the body can tolerate. On Rapa Nui, it is estimated that 90 percent of the population's salt intake might have come from brackish water consumption (Brosnan et al. 2018; Norton 1992). 


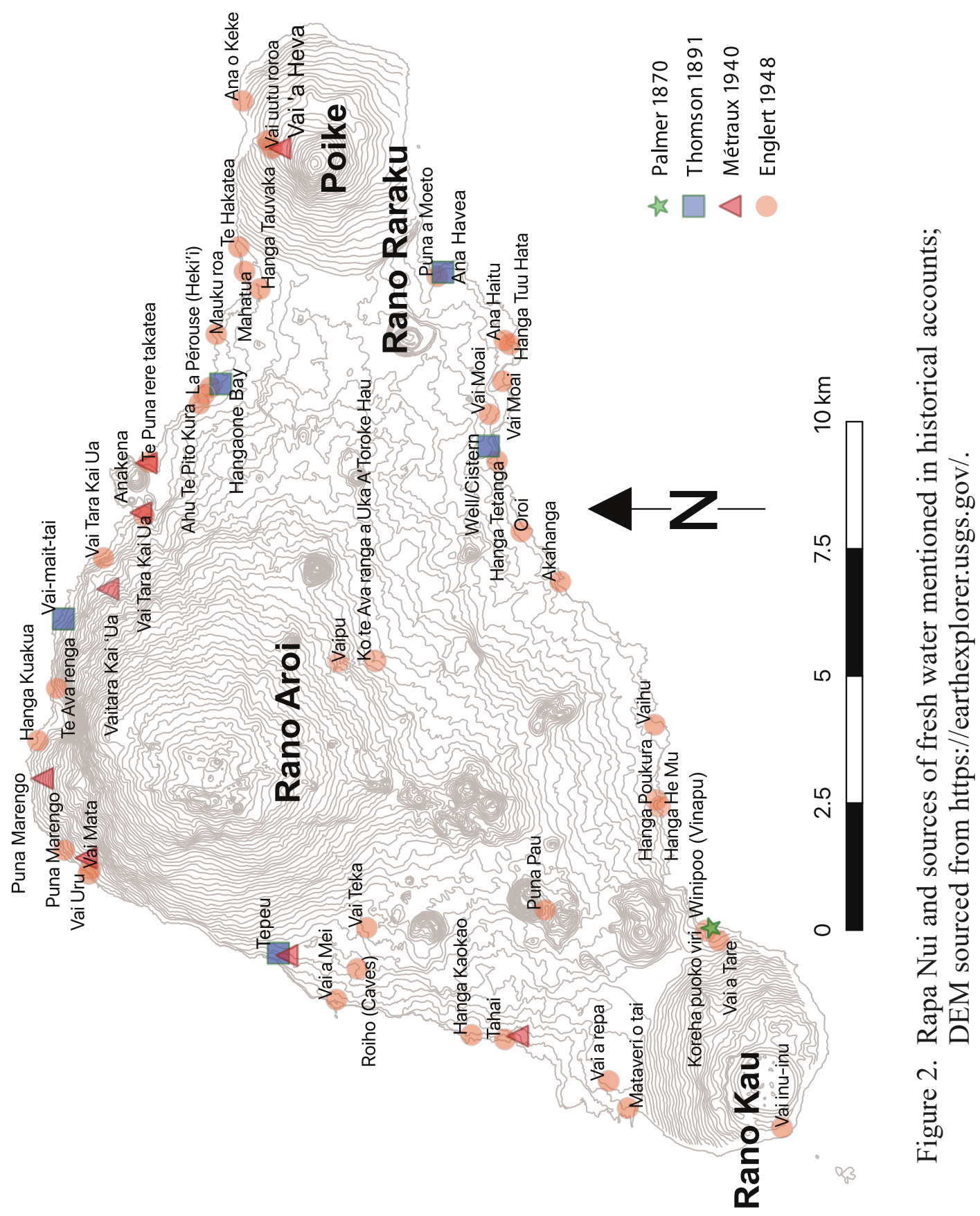




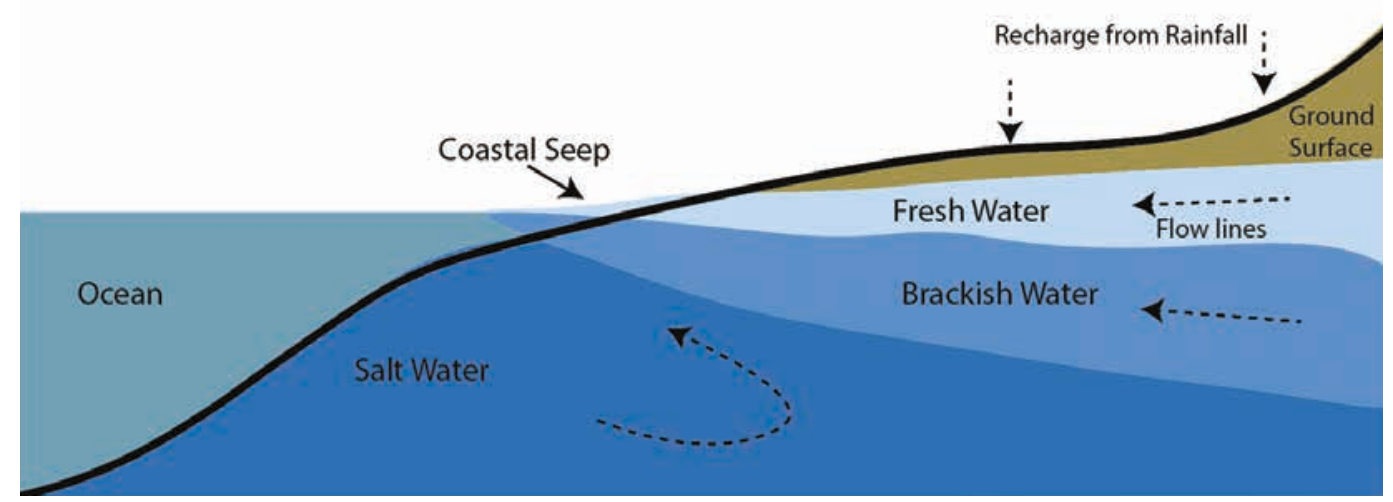

Figure 3. Schematic of hydrogeological model for Rapa Nui. Water from rainfall quickly enters the porous volcanic ground and flows towards the coast. Fresh water floats atop salt water that enters the ground from the ocean. At low tide, the lens of fresh water emerges at the coast. Where fresh water mixes with salt water, the resulting water is brackish.

\section{HISTORICAL ACCOUNTS OF FRESHWATER USE: 1722-1956}

European accounts of Rapa Nui began with the arrival of the Dutch captain Jacob Roggeveen, who sighted the island on Easter Sunday, 1722. Roggeveen's visit was a short one of just two days. Nearly five decades passed until the Spanish captain Don Felipe González arrived in 1770. This visit was followed in 1774 by the English captain James Cook and then in 1786 by French explorer Jean-François Galaup de La Pérouse. After this time, European explorers, missionaries, traders, whalers and, most tragically, slave raiders repeatedly visited Rapa Nui (Fischer 2005; Maude 1981). These earlier voyagers made a variety of observations about the natural and cultural features they encountered on the island (Richards 2008), including fresh water and its uses.

The first relatively thorough descriptions of the island's archaeology can be traced to John Linton Palmer, who arrived as a surgeon on the HMS Topaze in 1868. In a brief account, Palmer (1870) provided some of the first basic descriptions of four ahu that he references on a map. Geiseler ([1883] 1995) added details to these basic descriptions. The first comprehensive survey of the island comes from William J. Thomson (1891). During his visit, Thomson walked the coastline of Rapa Nui and described 113 ahu. In 1914, Katherine Routledge (1919) travelled to Rapa Nui and spent 16 months doing survey, excavations and interviews that resulted in detailed archaeological and ethnographic information on the island and its inhabitants. In 1934-35, Alfred Métraux $(1940,1957)$ of the Franco-Belgian expedition conducted 
ethnographic documentation that expanded upon Routledge's work. At around the same time, Father Sebastian Englert, a Catholic priest and prolific observer, arrived and lived on the island for more than 30 years. Englert's $(1948,1970)$ detailed documentation of more than 40 natural freshwater sources and numerous water-management features provides a significant source of knowledge on these issues. In 1955-56, Thor Heyerdahl led an international team for field research on Rapa Nui that included extensive documentation and excavations (Heyerdahl and Ferdon 1961).

One feature that unites these visitors and distinguishes them from more recent researchers is their heavy reliance on traditional local sources of fresh water during their visits. Since the mid-twentieth century, residents and visitors have become dependent on obtaining drinking water from wells sunk into the deep groundwater or from imported bottled water. Predating the era of contemporary well technology or regular and frequent cargo deliveries, residents, visitors and foreign researchers had to find drinkable water where they could. Thus, these historic notes offer relatively keen observations about the island's freshwater resources. More importantly, while these earlier ethnohistoric sources are often fragmentary, they provide some of the best available evidence for freshwater use by ancient Rapanui.

\section{Coastal Groundwater Discharge}

The earliest European visitors on Rapa Nui provide only limited information about the sources of fresh water used by Rapanui. During the first European visit in 1722, Roggeveen makes no reference to fresh water, though Captain Cornelis Bouman, in command of the Thienhoven, mentions water obtained by local populations that he "tasted and found to be quite brackish" (von Saher 1994: 99). Given the hydrogeology of the island described above, it is likely that Bouman's brackish water came from a coastal seep.

While the 1770 visit by the Spanish provides only a brief comment on the brackish nature of the drinking water they were provided with (Ruiz-Tagle 2004), the expedition in 1774 led by Captain Cook provides more details about fresh water on Rapa Nui. Cook (Ruiz-Tagle 2004: 160), for example, notes that Rapanui brought members of the English expedition that had travelled inland to "brackish and stinking" water that was only "rendered acceptable by the extremity of their thirst". Later, Cook mentions that the islanders even brought the inland party "real salt water" (p. 162). The fact that some of the islanders "drank pretty plentifully" of this seawater shocked Cook, who comments that "so far will necessity and custom get the better of nature!” (p. 162).

Cook indirectly mentions the source of this apparent seawater when he refers to the water collected from Rapa Nui: "The little we took on board could not be made use of; it being only salt water which had filtrated through 
a stony beach, into a stone well. This the natives had made for the purpose, a little to the Southward of the sandy beach so often mentioned; and the water ebbed and flowed into it with the tide" (p. 167). Through this reference, Cook became the first European to mention Rapanui use of a freshwater resource that is now recognised as a coastal seep (Fig. 4).

Cook's naturalist, Johann Forster, made specific notes about the lack of water on the island and correctly identifies the role of the island's geology. He notes that water availability is influenced by "those different porous substances, dry and burnt, that make the island dry and arid, as the rain gets absorbed and the plants cannot draw water from the dry and spongy ground, so they are not able to spread sufficiently to cover [the soil] and retain humidity, so necessary for the vegetation. This dryness influences not only the vegetable kingdom, but also animals and people" (Jakubowska

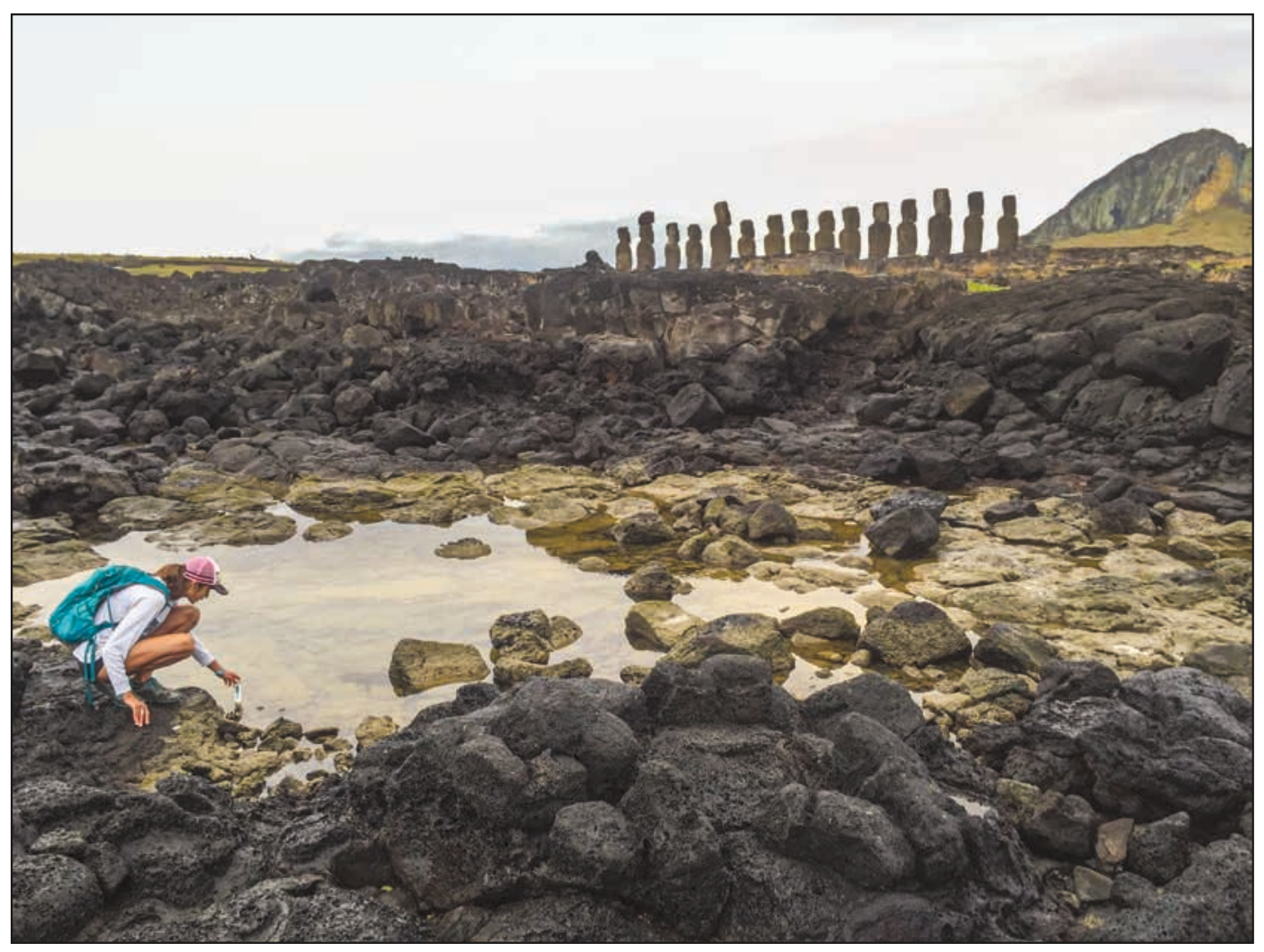

Figure 4. Coastal seep behind Ahu Tongariki on the south coast of Rapa Nui. This location is likely near where Routledge took a photograph of a freshwater pool emerging at the coast. The 1960 tsunami, however, dramatically altered the area. Here, Tanya Brosnan (California State University Long Beach) measures the conductivity of the water to determine the relative salt content. Photograph by Carl Lipo, 2015. 
2014: 79). He also comments that much of the water consumed was brackish given the mixing that occurs at coastal seeps between the ocean and fresh groundwater. For example, Forster (p. 83) states "water from several wells existing on the island is his usual drink; it is almost always brackish or has an admixture of other saline solutions, nevertheless that does not render it nasty or unhealthy for the inhabitants". His mention of "wells" likely refers to traditional features called puna, which we discuss in more detail below.

The use of coastal groundwater discharge directly at the tide line, however, caused some confusion among Europeans as to whether Rapanui were capable of drinking directly out of the ocean. Forster ([1777] 2000: 323), for example, notes that "some of our people really saw them drink of the sea-water when they were thirsty". Later observers often made the same mistaken observation. La Pérouse (Dos Passos 1971: 61), who visited the island in 1786, writes, "I have seen the natives of Easter Island drink the sea water like the albatrosses at Cape Horn." This misunderstanding of the use of coastal groundwater discharge gained popular use through the early nineteenth century when numerous whaling ships stopped by the island for supplies. For example, James Wolf (Richards 2008: 54), a mate on the HMS Blossom, writes during his ship's visit to the island in November 1825: "Pérouse says he had seen these people drink salt water like the albatross off Cape Horn, though his officers discovered a spring of less saline nature. This fact I may collaborate by one of our party having witnessed a native stooping down on the rocks and slaking his thirst from the water of the great Pacific Ocean." A later account by Captain Du Petit-Thouars of the Venus in February 1838 omits any mention of even brackish water and instead claims that "the natives are accustomed to drinking sea water" (p. 75). Though Rapanui use of coastal seeps evidently existed through this time, many early European visitors apparently lacked a clear understanding of what they were seeing.

William Thomson, paymaster aboard the USS Mohican, visited the island in 1886. During his visit, Thomson noted at least five locations around the coast that provided fresh water (Fig. 2), and most of the water he found was likely from coastal seeps. As he observes: "The so-called springs are holes into which the sea-water percolates, and are as salt [sic] as the ocean, at high tide, and decidedly brackish at all other stages" (Thomson 1891: 491).

Writing in 1919, Katherine Routledge provides an excellent description of the hydrology of the island. She states that "owing to the porous nature of the ground the water sinks beneath the surface, sometimes forming underground channels from which it flows into the sea below high-water mark: thus giving rise to the curious statement of early voyagers that the natives were able to drink salt water" (Routledge 1919: 132). Routledge provides a photo of a pool formed by water emerging from the ground along the coast behind Ahu Tongariki (Fig. 4). 
At the time of Routledge's visit, the dominant use of the island's landscape was for sheep ranching. Beginning in 1888, the Williamson-Balfour Company managed up to 60,000 sheep on Rapa Nui and used islanders as indentured labourers (Fischer 2005). In 1920, with the visit of biological engineer William Bryan, the ranch management started to recognise the value of coastal groundwater discharge for providing fresh water to the sheep herds. In his report including recommendations to increase ranch productivity, Bryan considers blasting "shallow wells at seepage sites and equip[ping] them with small windmills" (Porteous 1981: 135).

In sum, the available historical descriptions of traditional freshwater use highlight the importance of coastal seeps for Rapanui people in the eighteenth and nineteenth centuries. The association of significant archaeological material around coastal seeps (i.e., ahu and moai) strongly suggests that these sources of drinking water were also key during pre-contact times (DiNapoli et al. 2019).

\section{Wells (Puna)}

One inherent drawback to reliance on coastal groundwater discharge is its relatively high salinity from mixing with seawater. Brown ([1924] 1979: 25) claims that Rapanui "never made salt like the Hawaiians, and never took salt water as a seasoning like the other Polynesians" to accommodate the relatively high levels of salt intake associated with use of coastal groundwater. Rapanui also possibly reduced their salt intake by accessing groundwater inland of the coastal mixing zone. As Herrera and Custodio (2008: 1340) describe, however, "there is no clear relationship between water-table elevation and salinity, and distance to the shore and salinity, although the trend is to find higher salinity closer to the shore."

Though lower levels of salinity can be found in more inland groundwater, these sources are more difficult to access given the island's low-lying water table. With modern drilling technology, it turns out that many inland sources are only moderately less saline than coastal groundwater. For example, samples collected from a borehole in Hanga Roa about $1.3 \mathrm{~km}$ from the coast, where the land surface is around 100 masl, yielded a slightly brackish salinity value $\left(570 \mathrm{mg} / \mathrm{L} \mathrm{Cl}^{-}\right)$in 2002 and a somewhat fresh salinity value $(484 \mathrm{mg} / \mathrm{L}$ $\mathrm{Cl}^{-}$) in 2003 (Herrera and Custodio 2008: 1337). These borehole samples are admittedly half as saline as the coastal groundwater samples and thus of greater use for drinking (p. 1337). It is important to keep in mind that the elevation of the water table at the Hanga Roa borehole is 2.35 masl and that digging wells to a depth of nearly $100 \mathrm{~m}$ without modern equipment would be highly impractical (p. 1334). Thus, deciding where to build a well with the maximum ease of construction and minimum salinity levels becomes a problem of optimisation. 
While Rapa Nui's thick and porous volcanic apron makes inland groundwater virtually inaccessible without modern drilling equipment, it does not eliminate the practicality of near-coastal wells. Several historic accounts mention the use of both inland and near-shore wells, thus suggesting that such wells did provide a useful source of relatively fresh groundwater. In 1774, Georg Forster noted the use of shallow coastal wells that were likely associated with areas of coastal groundwater discharge. Forster ([1777] 2000: 327) writes, "[W] met Captain Cook, whom the natives had conducted to a well very close to the sea, which was cut deep into the rock, but full of impurities. When our people had cleared it, they found the water in it rather brackish, but the natives drank of it with much seeming satisfaction." Similarly, in 1786, La Pérouse (Dos Passos 1971: 61) notes that "a little brackish water was found in some holes on the sea shore".

In 1868, Palmer provided the first account that identified a specific location for a shallow near-coastal well (puna, Fig. 2). Palmer (1870: 168) states:

[A]s to the supply of fresh water on the island, a good deal of misapprehension has existed. In several of the craters there are many deep pools of it; in those of the Terano Kao [Rano Kau] these are fully 25 feet deep, and I have tasted it pure and fresh from many places, near the shore. At Winipoo [Vinapu], not only is there a subterranean reservoir (to which a tunnel leads from the face of the cliff), but on the very sea beach the natives have made a cistern to catch the water which distils from a little tunnel.

In this passage, Palmer mentions the location of a coastal seep that is near Ahu Vinapu on the southwest coast of the island. He also points out that water is available in the crater lakes and in at least one cave (we discuss descriptions of these additional sources of fresh water below).

Thomson (1891: 491) later mentions a puna during his visit, but he also calls the feature a "cistern". Specifically, at a location on the south coast near Tongariki, he (p. 491) describes a set of features in which "only the remains of walls and cisterns were found ... They were generally small, the largest being 9 feet in diameter, 14 feet deep, and surrounded by a sloping bank paved with small stones to facilitate the collection of rain water."

Métraux (1940) makes the first detailed discussion of puna, which are equivalent to the relatively shallow near-coastal wells first noted by Georg Forster and later described as cisterns by Palmer and Thomson. Métraux (p. 11) states that puna served a double function as reservoirs "which impounded rain water and perhaps some fresh water springs". He adds significance to such wells by observing that "ruins of ancient settlements are always thick around water holes" (p. 11). Métraux (1940: 11) goes on to describe a puna (Fig. 5): 
A deep ditch, between 2 and 3 meters deep, is dug near the shore. The seaward, lateral sides are perpendicular and lined with stones perfectly fitted. The landward side slopes at an angle of 45 degrees to the base of the opposite wall and is paved with boulders. After a rain the running water is led to the interior of the basin where, at the same time, water from the underground water body collects ... According to my informant, there is always water in them even though it does not rain.

Puna, therefore, enabled people to both access groundwater and reduce its salinity by limiting mixing with seawater and aiding rainwater catchment. Métraux (1957: 65) specifically adds that "the ancestors of the modern natives sought to prevent salt water from mingling with the fresh by constructing walls that formed a kind of reservoir".

Métraux (1940: 11) provides a specific location for one of these features at Vai a Hoa near Ovahe on the north shore. He also mentions that "at Tahai there is a kind of basin, separated from the sea by a wall, where fresh water mixes with salt water" (p. 11). Such walls designed for pooling coastal groundwater are likely similar to those noted by members of Cook's 1774 expedition. By the time of Métraux's writings, however, only "the cattle are watered there" (p. 11), and he notes that "a few of these reservoirs or springs still contain water, but most of them are filled with mud" (Métraux 1957: 65; see also Englert 1948: 219).

Heyerdahl (1961:26) also notes the close association of puna with areas of coastal groundwater discharge when he writes that "a short distance inland from such places [of coastal seeps], [Rapanui] had occasionally constructed an artificial well with retaining masonry walls". Like Métraux, Heyerdahl (p. 26) noticed that the water in puna becomes brackish when it is mixed with salt water at high tide.

Englert records an oral tradition relevant to the discussion of puna. According to this oral tradition, the scarcity of fresh water on Rapa Nui concerned Hotu Matu'a (the legendary first settler on the island). Englert (1970: 84) records, "Hotu Matu'a's concern led him to the discovery that shallow wells could be excavated on the extreme edge of the coast, which would produce water somewhat contaminated by the sea but still fit for human use. He had such wells dug at several points." Though the age of this oral tradition cannot be established, it does suggest the past importance and early use of puna and coastal seeps.

Recognising the essential role that freshwater sources have for communities, Englert (1948) provided one of the most comprehensive summaries of locations in which water was collected (see Fig. 2). Englert (p. 219) notes that these coastal seeps are quite abundant but often brackish and thus likely were the main dietary source of salt. He (p. 220) lists 21 coastal seep locations but admits that these are merely the significant locations, the 


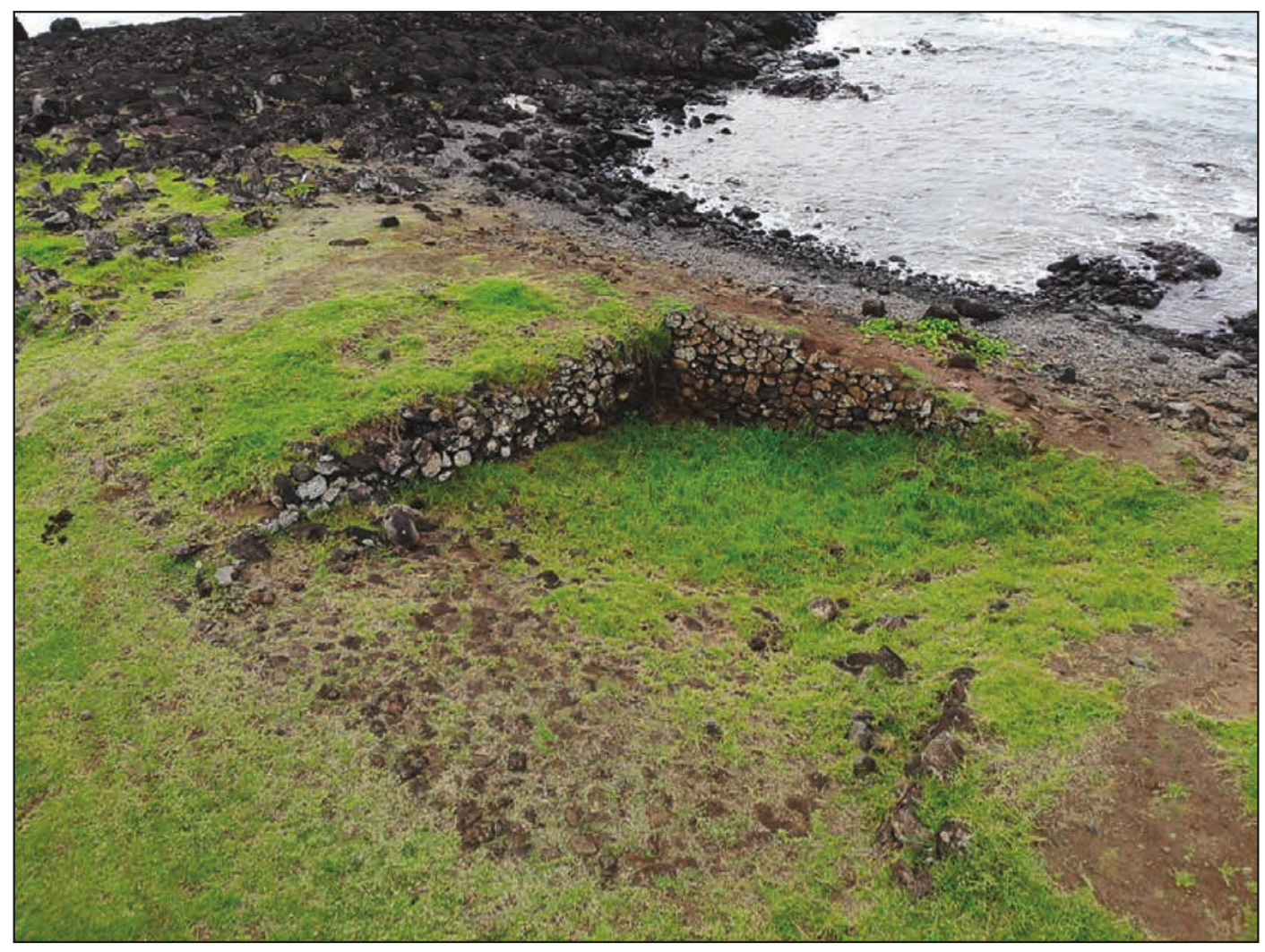

Figure 5. A coastal well (puna) feature located on the north coast of Rapa Nui near Ahu Ra'ai. Photograph by Terry Hunt, 2015.

full list being beyond the scope of his book. These include Mataveri o tai, Tahai, Hanga Kaokao, Hanga Kuakua, Te Ava Renga, Te Puna rere takatea, Mauku roa, Te Pito Kura, La Pérouse (Heki'i), Hanga Tauvaka, Mahatua, Te Hakatea, Puna a Moeto, Hanga Tu'u Hata, Ana Haitu, Vai Moai, Hanga Tetenga, Akahanga, Vaihu/Hanga Tee, Hanga He Mu and Koreha puoko viri. Some of these features are quite elaborate. Vai Moai, for example, is a large constructed well located between Hanga Tu'u Hata and Hanga Tetenga that consists of a paved slope $5 \mathrm{~m}$ wide and $80 \mathrm{~m}$ long (p. 220). Similarly, Englert (p. 221) describes the well at Vaihu/Hanga Tee as composed of a long tank that once defended fresh water against mixing with seawater.

\section{Inland Springs and Reservoirs}

Springs occur where a groundwater aquifer is filled to the point that the water overflows onto the land surface. However, the porous nature of the island's geology provides only limited areas where springs occur above the coastline. Observations from the Spanish expedition to Rapa Nui in 1770 give one reference to an inland spring. Specifically, Sublieutenant Don Juan Hervé 
provides only a passing reference to a spring that his group discovered when they dug pits for planting three wooden crosses on the northeastern side of the island: "At the moment of digging the hole on the centre hill, a fine spring of fresh water broke out, very good and abundant" (Ruiz-Tagle 2004: 91).

Cook (Ruiz-Tagle 2004: 161) too notes the existence of an inland spring when he writes that "towards the Eastern end of the island, they met with a well whose water was perfectly fresh, being considerably above the level of the sea". Cook (p. 161) also mentions that the islanders used this well to bathe. In contrast to this perfectly fresh spring, Cook (p. 285) notes that "on the declivity of the mountain [Terevaka?] towards the West, they met with another well; but the water was a very strong mineral, had a thick green scum on the top, and stunk intolerably".

Georg Forster of Cook's expedition also mentions the use of an inland well. Forster ([1777] 2000: 590) notes, "From this spot we continued our march a good way inland, and were conducted to a deep well, which appeared to have been formed by art, and contained good fresh water, though somewhat troubled." The inland locations and elevations of the described wells suggest that these wells were built around perched springs that formed due to the few impermeable volcanic dikes that crosscut the island's porous apron. While such features are relatively rare on Rapa Nui, Englert (1948: 218-19) documents about one dozen inland springs: Vai inu-inu, Puna Pau, Roiho, Vai teka, Vai taka-tiki, Vai tapu iru, Te Pahu, Roiko, Puna Marengo, Vai Uru, Vai Tara Kai Ua, Ana o Keke and Oroi. Métraux (1957: 66) documents two of these features. Dudgeon and Tromp (2014) use freshwater diatoms identified in the dental calculus of prehistoric Rapanui to argue for past reliance on inland spring water. Still, the output of these springs likely pales in comparison to that of coastal seeps. Additionally, the correspondence between the abundance of freshwater diatoms in dental calculus and the magnitude of reliance on fresh versus brackish drinking water is unclear.

Thus, in cases when the subsurface lacked sufficient permeability for fresh water to immediately enter the ground, it appears that Rapanui people modified the landscape to create pools. The best-known example of this activity can be found at Ava Ranga Uka A Toroke Hau (Vogt and Moser 2010). In a gully that runs south from Terevaka and near an ahu, Vogt and Kühlem (2018) have documented an elaborate set of water-retention features that include a stone-lined basin and possible dam feature. Stevenson (1997: 142) has also documented similar features possibly used for water diversion at the agricultural complex on Maunga Tari. Such features on the island are rare, yet further detailed surveys might reveal similar inland structures.

It should be noted that some authors (e.g., Heyerdahl and Ferdon 1961) claim that ravines on the slopes of Terevaka are indicative that the island 
once was much wetter and that streams were present. Heyerdahl (1961: 26), for example, notes, "A limited number of dry ravines are observed in the basalt on the north coast, some with series of whirlpool depressions and other apparent evidence of such a considerable water erosion that it is tempting to suspect that they once contained permanent streams." Métraux, however, correctly noted that "the little ravines [known as ava] that furrow the slopes of its hills are volcanic in origin" (Métraux 1957: 65). Indeed, the porous substrate can account for the absence of permanent streams even during relatively wet times.

\section{Lava Tubes and Caves}

The subsurface of Rapa Nui is relatively rich in caves and lava tubes (Ciszewski et al. 2009). These tubes form when lava flows beneath the hardened surface. As solid basalt, the floors of these tubes can be impermeable and can collect substantial amounts of fresh water that percolates from the surface.

In 1774, Georg Forster became the first European visitor to mention the presence of caverns on Rapa Nui, but he states that his group did not enter any of them because "the natives always refused to admit us" (Forster [1777] 2000: 341). Palmer (1870: 168) later mentions a "subterranean reservoir" that exists in a lava tube pool at Vinapu. Routledge provides an extensive discussion of Rapa Nui caves, but she mostly describes them as places of burial and storage. She does mention, however, that "in one district underground ways filled with water extend to a great length, and the whole surface rings hollow to the tread of a horse" (Routledge 1919: 272). Unfortunately, Routledge does not specify whether or not this water is fresh. Heyerdahl comments that lava tubes provided useful access to freshwater springs and claims that "subterranean springs with evidence of early human improvements are ... located at the floor of some of the deepest and largest underground caves, especially inland from Ovahe bay and near Vaihu" (Heyerdahl 1961: 26). He also notes that "a dependable subterranean water pool with good fresh water is found inland in the rocks of Vai-tara-kau-ua, where the fairly deep descent to the pool is artificially narrowed by large blocks, barely allowing a passage wide enough for one person" (p. 26).

Given the limited references to freshwater use in lava tubes, little can be said on the topic based on European accounts. It is possible that they were used throughout the historic period outside of the observations of European visitors. While caves are fairly common, the presence of water sources in them is less consistent. When water was available, these sources were likely used, although they were far sparser than the more consistent water found along the coastal margins of the island. 
Crater Lakes

The only perennial bodies of surface fresh water on the island are the steepsided crater lakes that exist where there are impermeable volcanic cores. There are three such lakes: in Rano Kau, Rano Raraku and Rano Aroi.

Given the size and depth of these three crater lakes and the lack of surface water elsewhere on the island, it is tempting to believe that Rapanui made early and extensive use of them. These bodies of water certainly have the potential to provide relatively stable sources of fresh water. Butler and Flenley (2010: 5), for example, argue that the lake at Rano Kau was "a permanent water supply for early inhabitants". Questioning the earliest dates known at Anakena (cf. Hunt and Lipo 2006, 2008), Flenley and Bahn (2007: 11) argue, "[I]s it not more likely that the early settlements would be near a good supply of fresh water, such as the crater lakes?"

While some researchers, in particular Rull and colleagues (e.g., Rull 2016, 2018, 2019; Rull et al. 2015, 2018), have recently emphasised the importance of fresh water from the craters at Rano Raraku and Rano Kau, even arguing that these were the only available water sources on the island (e.g., Rull 2018), there is little historical or archaeological evidence that the lakes were important sources of drinking water. There is some evidence, in the form of terrace features and plant microfossils, that the lakes may have been the focus of limited horticultural and/or domestic activity (e.g., Ferdon 1961a, 1961b; Horrocks, Baisden, Flenley et al. 2012; Horrocks, Baisden, Nieuwoudt et al. 2012; Horrocks et al. 2015; McCoy 1976). Additionally, the area around Rano Raraku was the primary location of moai carving, and the ceremonial site of 'Orongo on Rano Kau was the centre of the island's famous Tangata Manu ("Bird Man") ceremony. However, unlike areas along the coast and spots inland, the edges of the lakes are comparatively devoid of domestic features such as earth ovens (umu), gardens (manavai), areas of lithic mulching, and houses that characterise much of the island's settlement pattern (e.g., McCoy 1976; Morrison 2012; Stevenson and Haoa Cardinali 2008). The lack of other resources (e.g., marine food, land for cultivation) coupled with the steep walls of the volcanic craters, particularly at Rano $\mathrm{Kau}$, made habitation in these areas less attractive. Thus, while drinkable water was available in the craters and likely consumed for activities that took place in these areas, these lakes were likely not daily sources of drinking water for pre-contact communities. Of course, further investigations into the deposits around the lakes may shed additional light on this topic.

Historic accounts support the conclusion that prehistoric Rapanui did not rely heavily on fresh water from the crater lakes. European visitors often commented on the presence of these lakes, but none state that Rapanui relied 
on these freshwater resources. In 1797, for example, John Myer, on board the sperm-whaling ship William, joined a landing party that the islanders led to Rano Raraku. He writes, "Several of them [Rapanui] presented us with water, and firewood, and made signs for us to follow them, which we did to a small pond, filled with stagnant water, the surface of which was a mass of animalcula, of a green colour" (Richards 2008: 22). Sainthill ([1870] 2000: 107), an officer on the HMS Topaze, observes that "though the craters contain an abundant supply [of fresh water], our guides drank little". Similarly, Geiseler ([1883] 1995) notes that the crater lakes could be used in times of emergency, but he does not provide any evidence for such use. He merely states that "the craters of Rana Kau [Rano Kau] and Rana Roraka [Rano Raraku] always present the richest of freshwater reservoirs and these would be capable of supplying the needs of a population even larger than the one on Rapanui" (Geiseler [1883] 1995: 75). Additionally, Thomson (1891) notes that the water from the Rano Raraku lake is abundant but not particularly palatable. He states: "Drinking-water, the great desideratum on the island, obtained from sources that form the crater of Rana Roraka [sic], was, owing to its animal and vegetable impurities, unpalatable" (p. 491).

Later historic sources also indicate that crater lakes were not important sources of fresh water. Routledge relied on water from Rano Raraku during some of her 1917 visit, but she did so only in the absence of other, more convenient sources. She notes that dependence on this water resource "rendered us tiresomely dependent on getting native labor" (Routledge 1919: 137). Brown ([1924] 1979: 25) also notes that Rapanui people used water in the crater lakes for laundry at the time of his visit: "A procession of native horsemen and horsewomen passes up the slope of Rano Kao here every Saturday with bundles of clothes to wash." Though Routledge and Brown present a few cases of crater-lake water use, Métraux (1940: 12) generally states that "the water of the crater lakes (rano) ... is apparently too inaccessible to have been much used". He goes on to write that the crater lakes "are difficult, and even dangerous, of access. Today as in the past the natives only draw water from them under the pressure of extreme necessity" (Métraux 1957: 66). Englert (1948: 217) similarly suggests that the lakes were not primary water sources for most of the island's population given the relative difficulty of access and lack of transport methods other than gourds. Heyerdahl's comments on the crater lakes mirror those of Englert and Métraux. Heyerdahl (1961:26), however, adds that recent modern piping from the lakes makes these reservoirs a more viable resource. Overall, despite the relatively large amount of water held in the crater lakes, these sources of fresh water appear to have been of limited use until quite recently. 
Carved Rainfall Basins: Taheta

As previously mentioned, puna serve a dual function by both allowing access to groundwater and catching rainfall. Métraux also mentions the possibility that the islanders previously carved basins into rock outcrops for the sole purpose of rainfall catchment. Métraux (1940: 12; see also Métraux 1957: 66) states, "I noticed on a few rocks near ancient settlements small rectangular depressions artificially carved. The natives explained them as tanks to collect rain water." Métraux (1940: 11) mentions a water catchment basin at Vai a Heva, where "a hole in a cliff where water collects has been carved all around into the form of a big human face". Englert (1948: 221-22) lists the names of six well-known carved rainwater basins: Vai a Tare, Vai a Repa, Vai a Mei, Vai uutu roroa, Vai a Heva and Vai a Are. He notes that there are hundreds of other features like this across the landscape in small and large sizes. These features are locally known as taheta and are typically ovoid or square in shape and often relatively small (e.g., less than $1 \mathrm{~m}$ in diameter) and shallow, though larger features occur (Fig. 6). Heyerdahl (1961: 26) also records the presence of taheta at several locations (e.g., Puna Marengo and Ahu Tepeu). In contemporary surveys, taheta features are quite common and are among the most numerous of prehistoric features found on the landscape. In Morrison's (2012) survey of the northwest coast, for example, taheta comprise $5.5 \%$ of all the features found.

Though numerous, taheta likely served as only a secondary water source for activities across the landscape and away from more substantial sources. The fact that most taheta are small and shallow suggests limited investment in them for long-term water storage. Englert (1948: 222) argues that these basins would go dry without sufficient rainfall and that Rapanui must have instead relied more heavily on spring water. Indeed, recent estimates of evaporation rates on Rapa Nui indicate that taheta cannot store sufficient water during the driest months (Brosnan et al. 2018). The timing and amount of rainfall on Rapa Nui are highly variable. Morrison's (2012) analyses of 60 years of rainfall demonstrate no regularity in the patterning of annual rainfall.

Despite Rapa Nui's unpredictable rainfall, references to rainfall catchments exist in historic and modern contexts. In 1774, Forster ([1777] 2000: 341) noted that the crew harnessed rainwater when a "smart shower falling on board the ship, enabled our people to collect a quantity of fresh water in the awnings and sails of the ship, which were spread to catch it". Additionally, Routledge (1919: 137) relied primarily on rainwater collected in barrels from the roof at Mataveri. Métraux (1940: 12) also notes that "today abundant water from the corrugated iron roofs is collected in tanks or barrels". Even as late as the 1980s, Porteous (1981: 177) states that many residents in Mataveri still "retain supplementary roof tanks" due to the slightly brackish nature of the water pumped from modern wells. 


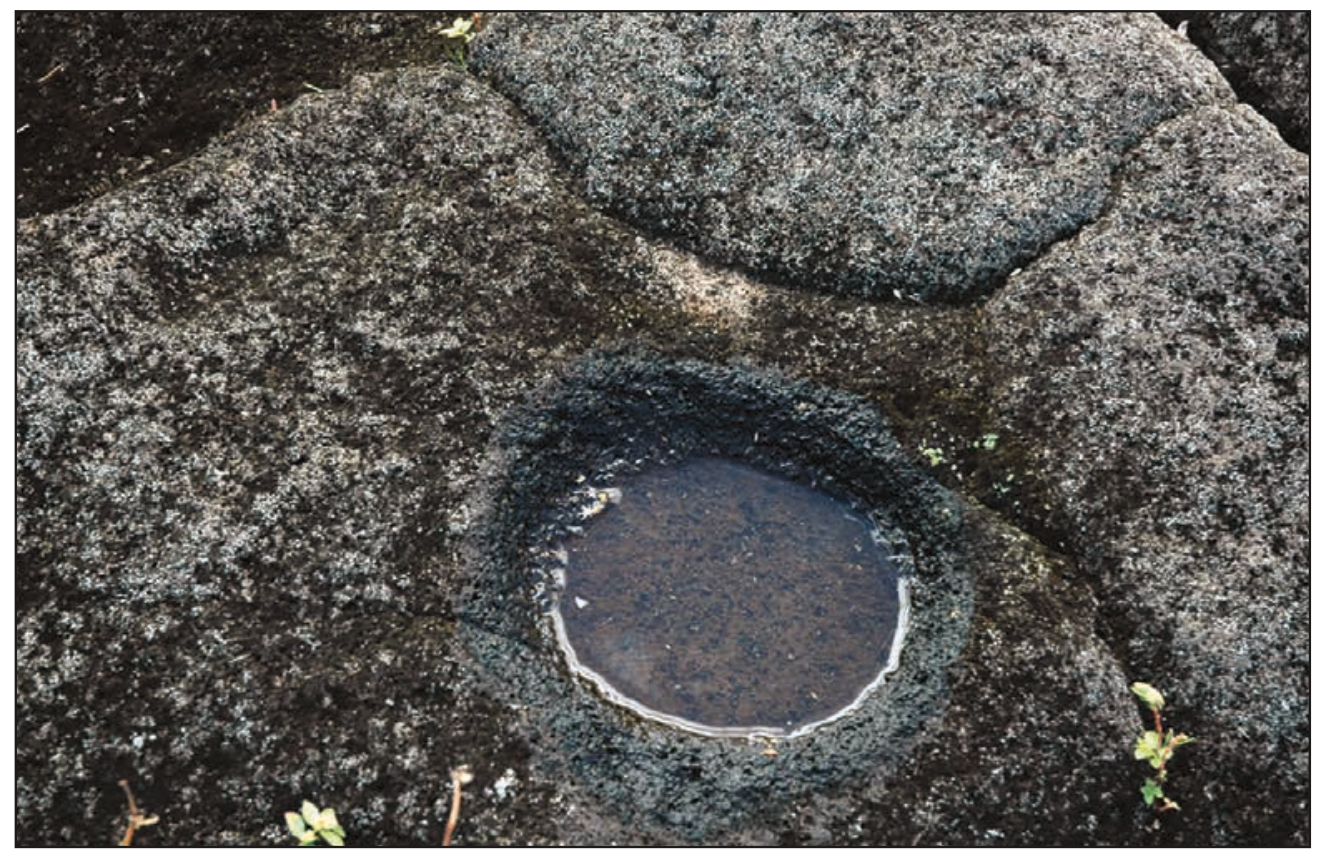

Figure 6. A shallow carved stone basin (taheta) for capturing rainwater. Photograph by Carl Lipo, 2015.

Sugarcane, Gourds and Moss

Historical sources suggest that Rapanui used several plants for past water procurement and storage. Mieth and Bork (2003) speculated that Rapanui may have consumed sap of the palm Jubaea chilensis. However, it is the consumption of sugarcane (Saccharum officinarum) as a thirst quenching plant that is documented in numerous historical accounts that start with Dutch captain Cornelis Bouman in 1722 (Dos Passos 1971: 68; Forster [1777] 2000: 327, 332; Geiseler [1883] 1995: 75; von Saher 1994: 99; Sainthill [1870] 2000: 107; Thomson 1891: 456).

Additionally, past visitors noticed that gourds (Lagenaria siceraria) were the primary tool for water transport. Bouman notes, "We found no furniture or pots, except calabashes in which they kept water which I tasted and found to be quite brackish" (von Saher 1994: 99). Though Cook observed that a scarcity of gourds for water storage meant that "a cocoa-nut shell was the most valuable thing we could give them" (Dos Passos 1971: 47), Thomson (1891: 29) later witnessed a profusion of bottle gourds that grew on the island. Englert (1948: 217) also notes the use of gourds for water storage. Relatively late accounts that start with Routledge (1919: 256) suggest that Rapanui used moss (Campylopus spp.) from the island's crater lakes to some extent "as a sponge to retain fresh water when at sea". 


\section{THE RELATIVE IMPORTANCE OF RAPA NUI'S FRESHWATER SOURCES}

Our review of ethnohistoric evidence of freshwater use indicates that while Rapanui used a range of natural freshwater sources (e.g., crater lakes, inland springs, coastal seeps, caves, rainwater) and management strategies (e.g., taheta, puna, large basins), some of these were likely more important than others. Use of rainwater and taheta appear to be opportunistic and impermanent solutions to the limited surface fresh water, as most taheta are small and shallow and would dry up during times of low rainfall (Brosnan et al. 2018). Inland springs and large water diversion and catchment features, such as those discussed at Ava Ranga Uka A Toroke Hau by Englert (1948) and identified archaeologically by Vogt and colleagues (Vogt and Kühlem 2018; Vogt and Moser 2010), were also used, but these were likely of lesser importance given their limited numbers. Rano Kau and Rano Raraku were important locations of ritual activity (the Tangata Manu ceremony and moai carving, respectively), and the crater lakes were likely used as water sources during these activities. However, ethnohistoric accounts suggest that the crater lakes were not primary freshwater sources in the post-contact era, likely because of their difficulty of access. This is also clearly reflected in the archaeological record: the vast majority of pre-contact settlements are located along the island's coasts and away from the crater lakes. The ethnohistoric and archaeological data indicate that coastal freshwater seeps, and the puna constructed to impound this water, were some of the most numerous and most often used freshwater sources. While ethnohistoric and hydrological studies demonstrate that these sources are often brackish, they nevertheless provided some of the most readily available sources of drinking water.

How the use and abundance of different freshwater sources documented in the ethnohistoric record relate to pre-contact times is a matter of debate. Several researchers have suggested that deforestation and/or climate changes directly reduced surface freshwater availability on the island (e.g., Bahn and Flenley 1992, 2017; Mieth and Bork 2018: 52; Rull 2018, 2019; Steadman et al. 1994; Vogt and Kühlem 2018). Some have also suggested that deforestation led to the disappearance of possible streams (e.g., Bahn and Flenley 1992: 178; Steadman et al. 1994: 93). The effects of deforestation on freshwater availability are unclear, however, and limited existing hydrogeological evidence supports these claims. Given the very porous nature of the island's volcanic substrate, it is unlikely that perennial streams were ever prominent on Rapa Nui. Even if we assume that the loss of the palm forest decreased the amount of available surface fresh water, the process of forest loss took several centuries (e.g., Horrocks et al. 2015; Hunt and Lipo 2009; Mann et al. 2008) and would have led to the increased importance of coastal freshwater seeps and the other water sources discussed. 
Regarding possible climatically induced droughts, some evidence for sedimentation and vegetation changes from cores taken from the island's crater lakes suggests that a drought possibly occurred from the 1500s to $1700 \mathrm{~s}$ (e.g., Cañellas-Boltà et al. 2013; Rull 2016). Rull (2016, 2018, 2019) argues that this drought would have necessitated population migration to Rano Kau to access its fresh water as other sources, such as coastal seeps, became depleted. While droughts are well documented historically and certainly would have reduced fresh water available from taheta and the crater lakes (e.g., a drought in 2018 left the crater lake at Rano Raraku nearly completely dry), the impact on coastal seeps is questionable. While Rapa Nui's fresh water, including in the crater lakes, is ultimately fed by rainwater, the discharge rates and massive volume of the island's freshwater aquifer suggest that coastal groundwater could possibly remain a stable source even through drought periods. The lakes would suffer from not only loss of water through subsurface flows (Montgomery \& Associates 2011) but also greater evaporation than groundwater. Thus, it is possible that the impacts of drought would be first observed in the lakes, as is occurring now. While there is some evidence for habitation and cultivation within and around Rano Kau crater, the density of archaeological features around the lake is insufficient to support claims of a large-scale abandonment of coastal areas. Indeed, throughout pre-contact and early historic times, most of the population lived along the coast, and both the ethnohistoric evidence presented here and recent archaeological analyses (e.g., DiNapoli et al. 2019) demonstrate the key importance of coastal water sources for Rapanui communities.

$$
\text { *** }
$$

As a volcanic island with a highly porous substrate, Rapa Nui's geology makes surface water scarce and inland groundwater difficult to access. Coupled with unpredictable rainfall, these hydrogeological conditions necessitated diverse and innovative strategies to procure this vital resource. Guided by an understanding of the island's hydrogeology and an examination of ethnohistoric accounts, our review suggests that Rapanui used a number of creative strategies to procure and store fresh water. While additional chronological information about the use of these strategies is needed, many of them (e.g., puna and taheta) are associated with pre-contact remains and can be attributed to pre-European water-resource management. Early accounts repeatedly noted Rapanui use of brackish water from pools in coastal areas. These sources were abundant and often enhanced with constructed nearcoastal "wells" known as puna, which improved access to groundwater and reduced its salinity. Water from coastal sources was likely stored using gourds and supplemented with water from the crater lakes, inland springs, lava tubes, 
taheta and sugarcane. Historical and archaeological evidence suggest it is unlikely that Rapanui relied heavily on water from the island's crater lakes, which challenges recent claims that the crater lakes were the only or most important sources of drinking water (e.g., Rull 2016, 2018, 2019; Rull et al. 2018). The diversity of freshwater procurement strategies and reliance on coastal seeps highlights the successful adaptations and resilience of Rapanui communities to the challenges posed by the island's marginal environment. Overall, the ability of Rapanui to thrive despite their limited access to fresh water is a remarkable feat that warrants recognition and further study through archaeological and hydrogeological field research.

Using this ethnohistoric information, in combination with recently published hydrogeological data (Brosnan et al. 2018), we now have a solid basis for generating hypotheses about how patterns in the archaeological record relate to freshwater access. For example, it is worth considering how the spatial distribution of community patterning, in particular Rapa Nui's dispersed settlement pattern (organised around group-level competitive and cooperative behaviour connected to ahu), may be related to the constraints imposed by the locations of fresh water on the island (e.g., DiNapoli et al. 2018: 216-17; Hunt and Lipo 2018; McCoy 1976). Our recent spatial analysis of the relationship between ahu and different environmental variables suggests that ahu locations are closely tied to the availability of fresh water and coastal freshwater sources in particular (DiNapoli et al. 2019). This analysis shows that previously described associations between ahu and fresh water (e.g., Vogt and Kühlem 2018; Vogt and Moser 2010) are indeed part of an island-wide pattern. However, further theoretical, field and analytical work is needed to more fully evaluate hypotheses for both the cooperative and competitive processes that underlie this pattern. Importantly, resolving these issues requires additional baseline research, such as functional classifications of freshwater features like puna and taheta, continued surveys of freshwater resources, and chronological data on the development of these freshwater procurement strategies. For example, chronological information on the development of puna would help resolve current uncertainties about the relationship between periods of drought and differential use of coastal versus lacustrine fresh water. At the same time, the demands on the island's water supply continue to grow with increases in the resident population, along with the ever-increasing numbers of tourists (Figueroa and Rotarou 2016). As pumping from contemporary wells begins to reach its limits, such information about historic sources of water likely will become key to future communities on the island. 


\section{ACKNOWLEDGEMENTS}

We would like to thank Comunidad Indígena Ma'u Henua, Consejo de Monumentos Rapa Nui, Consejo de Monumentos Chile, CONAF, COEIPA and the people of Rapa Nui for allowing us to work on their island. We also thank Matt Becker and Tanya Brosnan for their central contributions to the understanding of the hydrogeology of Rapa Nui, and Hetereki Huke, Gina Pakarati and Tiare Aguilera for their guidance and support, without which this research would not be possible. We also thank Melinda Allen and two anonymous reviewers for their helpful comments on the paper.

\section{REFERENCES}

Álamos y Peralta, 1992. Recursos hídricos de Isla de Pascua: Estudio del regadío de Isla de Pascua, I etapa: Estudio hidrogeológico [Water resources of Easter Island: Study of Easter Island irrigation, 1st stage: Hydrogeological study]. Santiago: Comisión Nacional de Riego.

Bahn, Paul and John Flenley, 1992. Easter Island, Earth Island. London: Thames \& Hudson.

2017. Easter Island, Earth Island: The Enigmas of Rapa Nui. Fourth edition. Lanham, MD: Rowman \& Littlefield.

Bonatti, E., E.C. Harriso, D.E. Fisher, J. Honnorez, J.G. Schilling, J.J. Stipp, and M. Zentilli, 1977. Easter volcanic chain (Southeast Pacific): A mantle hot line. Journal of Geophysical Research 82 (17): 2457-78.

Brosnan, Tanya, Matthew W. Becker and Carl P. Lipo, 2018. Coastal groundwater discharge and the ancient inhabitants of Rapa Nui (Easter Island), Chile. Hydrogeology Journal 27 (2): 519-34. DOI: https://doi.org/10.1007/s10040018-1870-7.

Brown, John Macmillan, [1924] 1979. The Riddle of the Pacific. First AMS edition. New York: AMS Press.

Butler, Kevin R. and John R. Flenley, 2010. The Rano Kau 2 pollen diagram: Palaeoecology revealed. Rapa Nui Journal 24 (1): 5-10.

Cañellas-Boltà, Núria, Valentí Rull, Alberto Sáez, Olga Margalef, Roberto Bao, Sergi Pla-Rabes, Maarten Blaauw, Blas Valero-Garcés and Santiago Giralt, 2013. Vegetation changes and human settlement of Easter Island during the last millennia: A multiproxy study of the Lake Raraku sediments. Quaternary Science Reviews 72: 36-48. DOI: 10.1016/j.quascirev.2013.04.004.

Ciszewski, Andrzej, Jan Ryn Zdzisław and Mariusz Szelerewicz (eds), 2009. The Caves of Easter Island: Underground World of Rapa Nui. Kraków, Poland: Pracownia Kreatywna.

DiNapoli, Robert J., Carl P. Lipo, Tanya Brosnan, Terry L. Hunt, Sean Hixon, Alex E. Morrison and Matthew Becker, 2019. Rapa Nui (Easter Island) monument (ahu) locations explained by freshwater sources. PLoS ONE 14 (1): e0210409.

DiNapoli, Robert J. and Alex E. Morrison, 2017. Human behavioural ecology and Pacific archaeology. Archaeology in Oceania 52 (1): 1-12. 
DiNapoli, Robert J., Alex E. Morrison, Carl P. Lipo, Terry L. Hunt and Brian G. Lane, 2018. East Polynesian islands as models of cultural divergence: The case of Rapa Nui and Rapa Iti. Journal of Island and Coastal Archaeology 13 (2): 206-23.

Dos Passos, John, 1971. Easter Island: Island of Enigmas. Garden City, NY: Doubleday.

Dudgeon, John V. and Monica Tromp, 2014. Diet, geography and drinking water in Polynesia: Microfossil research from archaeological human dental calculus, Rapa Nui (Easter Island). International Journal of Osteoarchaeology 24 (5): 634-48.

Dyson-Hudson, Rada and Eric A. Smith, 1978. Human territoriality: An ecological reassessment. American Anthropologist 80 (1): 21-41.

Englert, Sebastian, 1948. La Tierra de Hotu Matu'a: Historia, Etnología, y Lengua de Isla de Pascua. Padre Las Casas, Chile: San Francisco.

1970. Island at the Center of the World: New Light on Easter Island. New York: Scribner.

Ferdon, Edwin N., 1961a. Stone houses in the terraces of Site E-21. In T. Heyerdahl and E.N. Ferdon (eds), Reports of the Norwegian Archaeological Expedition to Easter Island and the East Pacific. Vol. 1, Archaeology of Easter Island. Stockholm: Forum Publishing House, pp. 313-21.

- 1961b. The ceremonial site of Orongo. In T. Heyerdahl and E.N. Ferdon (eds), Reports of the Norwegian Archaeological Expedition to Easter Island and the East Pacific. Vol. 1, Archaeology of Easter Island. Stockholm: Forum Publishing House, pp. 221-55.

Figueroa, Eugenio and Elena S. Rotarou, 2016. Tourism as the development driver of Easter Island: The key role of resident perceptions. Island Studies Journal 11 (1): 245-64.

Fischer, Steven R., 2005. Island at the End of the World: The Turbulent History of Easter Island. London: Reaktion.

Flenley, John R. and Paul Bahn, 2007. Conflicting views of Easter Island. Rapa Nui Journal 21 (1): 11-13.

Forster, Georg, [1777] 2000. A Voyage Round the World. Translated by N. Thomas and O. Berghof. Honolulu: University of Hawai'i Press.

Geiseler, Wilhelm, [1883] 1995. Die Oster-Insel: Eine Stätte prähistorischer Kultur in der Südsee. Translated by William S. Ayers. Honolulu: University of Hawai' $i$ Press.

Herrera, Christian and Emilio Custodio, 2008. Conceptual hydrogeological model of volcanic Easter Island (Chile) after chemical and isotopic surveys. Hydrogeology Journal 16 (7): 1329-48.

Heyerdahl, Thor, 1961. An introduction to Easter Island. In T. Heyerdahl and E.N. Ferdon (eds), Reports of the Norwegian Archaeological Expedition to Easter Island and the East Pacific. Vol. 1, Archaeology of Easter Island. Stockholm: Forum Publishing House, pp. 21-90.

Heyerdahl, Thor and Edwin N. Ferdon (eds), 1961. Reports of the Norwegian Archaeological Expedition to Easter Island and the East Pacific. Vol. 1: Archaeology of Easter Island. Stockholm: Forum Publishing House. 
Hochstetter, Francisco Torres, Sergio Rapu Haoa, Carl P. Lipo and Terry L. Hunt, 2011. A public database of archaeological resources on Easter Island (Rapa Nui) using Google Earth. Latin American Antiquity 22 (3): 385-97.

Horrocks, M., W.T. Baisden, J. Flenley, D. Feek, L. González Nualart, S. HaoaCardinali and T. Edmunds Gorman, 2012. Fossil plant remains at Rano Raraku, Easter Island's statue quarry: Evidence for past elevated lake level and ancient Polynesian agriculture. Journal of Paleolimnology 48 (4): 767-83. DOI: 10.1007/ s10933-012-9643-0.

Horrocks, M., W.T. Baisden, M.A. Harper, M. Marra, J. Flenley, D. Feek, S. HaoaCardinali, E.D. Keller, L. González Nualart and T. Edmunds Gorman, 2015. A plant microfossil record of Late Quaternary environments and human activity from Rano Aroi and surroundings, Easter Island. Journal of Paleolimnology 54 (4): 279-303. DOI: 10.1007/s10933-015-9852-4.

Horrocks, M., W.T. Baisden, M.K. Nieuwoudt, J. Flenley, D. Feek, L. González Nualart, S. Haoa-Cardinali and T. Edmunds Gorman, 2012. Microfossils of Polynesian cultigens in lake sediment cores from Rano Kau, Easter Island. Journal of Paleolimnology 47 (2): 185-204. DOI: 10.1007/s10933-011-9570-5.

Hunt, Terry L. and Carl P. Lipo, 2006. Late colonization of Easter Island. Science 311 (5767): 1603-06. DOI: 10.1126/science.1121879.

-2008. Evidence for a shorter chronology on Rapa Nui (Easter Island). Journal of Island and Coastal Archaeology 3 (1): 140-48. DOI: 10.1080/15564890801990797. 2009. Revisiting Rapa Nui (Easter Island) “ecocide”. Pacific Science 63 (4): 601-16. DOI: 10.2984/049.063.0407.

2018. The archaeology of Rapa Nui (Easter Island). In E.E. Cochrane and T.L. Hunt (eds), The Oxford Handbook of Prehistoric Oceania. New York: Oxford University Press, pp. 416-49.

Jakubowska, Zuzanna, 2014. Still More to Discover: Easter Island in an Unknown Manuscript by the Forsters from the 18th Century. Warsaw: Muzeum Historii Polskiego Ruchu Ludowego.

Kim, Guebuem, Kang-Kun Lee, Kwan-Suk Park, Dong-Woon Hwang and Han-Soeb Yang, 2003. Large submarine groundwater discharge (SGD) from a volcanic island. Geophysical Research Letters 30 (21): 1-4. DOI: 10.1029/2003GL018378.

Mann, Daniel, James Edwards, Julie Chase, Warren Beck, Richard Reanier, Michele Mass, Bruce Finney and John Loret, 2008. Drought, vegetation change, and human history on Rapa Nui (Isla de Pascua, Easter Island). Quaternary Research 69 (1): 16-28.

Maude, Henry Evans, 1981. Slavers in Paradise: The Peruvian Slave Trade in Polynesia, 1862-1864. Stanford, CT: Stanford University Press.

McCoy, Patrick C., 1976. Easter Island Settlement Patterns in the Late Prehistoric and Protohistoric Periods. New York: Easter Island Committee.

Métraux, Alfred, 1940. Ethnology of Easter Island. Bernice P. Bishop Museum, Honolulu, Hawai'i.

1957. Easter Island: A Stone Age Civilization of the Pacific. New York: Oxford University Press. 
Mieth, Andreas and Hans-Rudolf Bork, 2003. Diminution and degradation of environmental resources by prehistoric land use on Poike Peninsula, Easter Island (Rapa Nui). Rapa Nui Journal 17 (1): 34-41.

2018. A vanished landscape-phenomena and eco-cultural consequences of extensive deforestation in the prehistory of Rapa Nui. In S. Haoa Cardinali, K.B. Ingersoll, D.W. Ingersoll Jr and C.M. Stevenson (eds), Cultural and Environmental Change on Rapa Nui. New York: Routledge, pp. 32-58.

Montgomery \& Associates, Inc., 2011. Condiciones Hidrogeológicas: Isla de Pascua, Chile. Report. Santiago: Government of Chile.

Moosdorf, Nils and Till Oehler, 2017. Societal use of fresh submarine groundwater discharge: An overlooked water resource. Earth-Science Reviews 171: 338-48.

Morrison, Alexander, 2012. An Archaeological Analysis of Rapa Nui Settlement Structure: A Multi-scalar Approach. PhD diss. University of Hawai ‘i, Mānoa.

Norton, Scott A., 1992. Salt consumption in ancient Polynesia. Perspectives in Biology and Medicine 35 (2): 160-81.

Palmer, J. Linton, 1870. A visit to Easter Island, or Rapa Nui, in 1868. Journal of the Royal Geographical Society of London 40: 167-81.

Porteous, J. Douglas, 1981. The Modernization of Easter Island. Western Geographical Series 19. Victoria, BC, Canada: Western Geographical Press, University of Victoria.

Richards, Rhys, 2008. Easter Island 1793-1861: Observations by Early Visitors before the Slave Raids. Los Osos, CA: Easter Island Foundation.

Routledge, Katherine, 1919. The Mystery of Easter Island. London: Sifton, Praed \& Co.

Ruiz-Tagle, Eduardo (ed.), 2004. Easter Island: The First Three Expeditions. Hanga Roa, Rapa Nui, Chile: Rapa Nui Press.

Rull, Valentí, 2016. Natural and anthropogenic drivers of cultural change on Easter Island: Review and new insights. Quaternary Science Reviews 150: 31-41. DOI: 10.1016/j.quascirev.2016.08.015.

2018. Strong fuzzy EHLFS: A general conceptual framework to address past records of environmental, ecological and cultural change. Quaternary 1 (2): 10. DOI: $10.3390 /$ quat1020010.

2019. Climate change, deforestation patterns, freshwater availability and cultural shifts on prehistoric Easter Island (SE Pacific). PeerJ Preprints 7: e27680v1. DOI: $10.7287 /$ peerj.preprints.27680v1.

Rull, Valentí, Núria Cañellas-Boltà, Olga Margalef, Alberto Sáez, Sergi Pla-Rabes and Santiago Giralt, 2015. Late Holocene vegetation dynamics and deforestation in Rano Aroi: Implications for Easter Island's ecological and cultural history. Quaternary Science Reviews 126: 219-26. DOI: 10.1016/j.quascirev.2015.09.008.

Rull, Valentí, Encarni Montoya, Irantzu Seco, Núria Cañellas-Boltà, Santiago Giralt, Olga Margalef, Sergi Pla-Rabes, William D’Andrea, Raymond Bradley and Alberto Sáez, 2018. CLAFS, a holistic climatic-ecological-anthropogenic hypothesis on Easter Island's deforestation and cultural change: Proposals and testing prospects. Frontiers in Ecology and Evolution 6: 32 pp. DOI: 10.3389/ fevo.2018.00032.

Sainthill, Richard, [1870] 2000. Rapa-Nui, or Easter Island, in November 1868. Rapa Nui Journal 14 (4): 107-10. 
Steadman, David W., Patricia Vargas Casanova and Claudio Cristino Ferrando, 1994. Stratigraphy, chronology, and cultural context of an early faunal assemblage from Easter Island. Asian Perspectives 33 (1): 79-96.

Stevenson, Christopher M., 1997. Archaeological Investigations on Easter Island: Maunga Tari: An Upland Agricultural Complex. Los Osos, CA: Easter Island Foundation.

Stevenson, Christopher M. and Sonia Haoa Cardinali, 2008. Prehistoric Rapa Nui: Landscape and Settlement Archaeology at Hanga Ho 'onu. Los Osos, CA: Easter Island Foundation.

Stevenson, Christopher M., Cedric O. Puleston, Peter M. Vitousek, Oliver A. Chadwick, Sonia Haoa and Thegn N. Ladefoged, 2015. Variation in Rapa Nui (Easter Island) land use indicates production and population peaks prior to European contact. Proceedings of the National Academy of Sciences 112 (4): 1025-30.

Thomson, William J., 1891. Te Pito Te Henua; Or, Easter Island. Washington, DC: Smithsonian Institution Press.

Vezzoli, Luigina and Valerio Acocella, 2009. Easter Island, SE Pacific: An endmember type of hotspot volcanism. Geological Society of America Bulletin 121 (5-6): 869-86.

Vogt, Burkhard and Annette Kühlem, 2018. By the quebrada of Ava Ranga Uka A Toroke Hau - about landscape transformation and the significance of water and trees. In S. Haoa Cardinali, K.B. Ingersoll, D.W. Ingersoll Jr and C.M. Stevenson (eds), Cultural and Environmental Change on Rapa Nui. New York: Routledge, pp. 113-32.

Vogt, Burkhard and Johannes Moser, 2010. Ancient Rapanui water managementGerman archaeological investigations in Ava Ranga Uka a Toroke Hau, 20082010. Rapa Nui Journal 24 (2): 18-26.

von Saher, Herbert, 1994. The complete journal of Captain Cornelis Bouman from 31 March to 13 April 1722 during their stay around Easter Island. Rapa Nui Journal 8 (4): 95-100.

Zeferjahn [Brosnan], Tanya L., 2016. Submarine Groundwater Discharge as a Freshwater Resource for the Ancient Inhabitants of Rapa Nui. Master's thesis. California State University at Long Beach.

\section{AUTHOR CONTACT DETAILS}

Corresponding Author: Sean W. Hixon, Department of Anthropology, Humanities and Social Sciences Building 2001, University of California, Santa Barbara, CA 93106-3210 USA.Email: hixon@ucsb.edu

Robert J. DiNapoli, Department of Anthropology, University of Oregon, Eugene, Oregon 97403, USA. Email: rdinapol@cas.uoregon.edu

Carl P. Lipo, Department of Anthropology, Binghamton University, Binghamton, New York 13902-6000, USA. Email: clipo@binghamton.edu

Terry L. Hunt, Honors College, University of Arizona, Tucson, Arizona 85719, USA. Email: tlhunt@email.arizona.edu 